\title{
PENGARUH BERKUMUR LARUTAN MADU TERHADAP INDEKS PLAK PADA SISWA-SISWI KELAS VI SD NEGERI 066038 KECAMATAN MEDAN TUNTUNGAN
}

\author{
Herlinawati \\ Jurusan Keperawatan Gigi Poltekes Kemenkes RI Medan
}

\begin{abstract}
Abstrak
Penyebab terjadinya karies gigi dan peradangan pada jaringan periodontal salah satunya adalah mikroorganisme yang terkandung dalam plak yang menempel pada permukaan gigi. Menyingkirkan plak dari permukaan gigi tidak hanya dilakukan dengan menyikat gigi saja, namun juga bisa dilakukan dengan cara berkumur dengan zat tertentu. Madu mampu menghentikan perkembangan bakteri di dalam mulut yang menyebabkan pengurangan lapisan plak sehingga dapat mempengaruhi penurunan indeks plak seseorang. Tujuan dari penelitian adalah untuk mengetahui pengaruh berkumur larutan madu terhadap indeks plak. Jenis penelitian yang dilakukan adalah metode quasi experiment (eksperimen semu) dengan rancangan pretest - postest one group desain. Penelitian ini dilakukan pada siswa-siswi kelas VI SD Negeri 066038 Medan Kecamatan Medan Tuntungan, dengan populasi 160 siswa-siswi dan sampelnya 40 orang. Hasil penelitian menunjukkan sebelum berkumur dengan larutan madu diketahui bahwa rata-rata indeks plak siswa-siswi kriteria baik tidak ada,kriteria sedang 1,58 dan 2,28 untuk kriteria buruk dan setelah berkumur dengan larutan madu rata-rata indeks plak untuk kriteria baik yaitu 0,72 dan kriteria sedang 0,14 dan kriteria buruk 2,10 Kesimpulan penelitian ini menunjukkan ada pengaruh berkumur larutan madu terhadap penurunan indeks plak dan diharapkan dapat menambah wawasan siswa-siswi SD Negeri 066038 Medan Kecamatan Medan Tuntungan.
\end{abstract}

Kata Kunci : : Larutan Madu, Indeks Plak

Daftar Bacaan : : 11 (1995-2014)

\section{PENDAHULUAN}

Kesehatan gigi dan mulut penting bagi kesehatan dan kesejahteraan tubuh secara umum dan sangat memengaruhi kualitas kehidupan, termasuk fungsi bicara, pengunyahan, dan rasa percaya diri. Gangguan kesehatan gigi dan mulut akan berdampak pada kinerja seseorang. Di Indonesia penyakit gigi dan mulut terutama karies dan penyakit periodontal masih banyak diderita, baik oleh anak-anak maupun usia dewasa. Sebagian besar masalah kesehatan gigi dan mulut sebenarnya dapat dicegah. Banyak cara untuk dapat mengurangi dan mencegah penyakit gigi dan mulut dengan berbagai pendekatan yang meliputi pencegahan yang dimulai pada masyarakat, perawatan oleh diri sendiri dan perawatan secara professional (Putri Megananda H. dkk., 2013).

Menurut Undang-Undang Kesehatan No.36 Tahun 2009 Pasal 93 ayat 1 dan 2 yaitu pelayanan kesehatan gigi dan mulut dilakukan untuk memelihara dan meningkatkan derajat kesehatan masyarakat yang dapat dilakukan dengan tindakan pencegahan penyakit gigi, serta pemulihan kesehatan gigi yang dilaksanakan oleh pemerintah setempat dan dapat juga di lakukan melalui pelayanan kesehatan gigi perorangan, sekolah dan masyarakat. Berdasarkan hasil Riset Kesehatan Dasar (2013), prevalensi nasional masalah gigi dan mulut mencapai 25,9 persen, sebanyak 14 provinsi mempunyai prevalensi masalah gigi dan mulut di atas angka nasional. Prevalensi nasional menyikat gigi setiap hari adalah 94,2 persen sebanyak 15 provinsi berada di bawah prevalensi nasional.

Salah satu penyebab terjadinya karies gigi dan peradangan pada jaringan periodontal adalah mikroorganisme yang terkandung di dalam plak yang menempel pada permukaan gigi. Karies gigi adalah penyakit multifaktor yang merupakan hasil kombinasi dari 4 (empat) faktor utama yaitu host (gigi), substrat, mikroorganisme di dalam plak dan waktu (Samaranayake, 2002). Plak gigi memegang peranan penting dalam menyebabkan terjadinya karies. Karies gigi merupakan suatu penyakit yang disebabkan oleh adanya interaksi plak kuman dengan diet dan gigi. Tidak diragukan lagi bahwa tanpa adanya plak maka tidak akan timbul karies. Akibatnya salah satu cara pencegahan karies adalah dengan mengusahakan agar pembentukan plak pada permukaan gigi dapat dibatasi, baik dengan cara mencegah pembentukannya atau dengan pembersihan plak dalam jangka waktu tertentu. Usaha-usaha untuk pengendalian plak umumnya mengikuti : cara mekanis dan cara kemis untuk menghambat pembentukan plak atau menghindari kuman spesifik dan produknya dalam plak.

Menyingkirkan plak dari permukaan gigi tidak hanya dilakukan dengan menyikat gigi saja, namun 
juga bisa dilakukan dengan cara berkumur dengan larutan madu. Larutan madu sangat efektif untuk mencegah kerusakan gigi. Larutan madu mampu menghentikan perkembangan bakteri di dalam mulut.

Pada survei awal di SD Negerii 066038 Medan terhadap beberapa siawa/siswi hampir $80 \%$ ditemukan adanya indeks plak dengan kriteria buruk. Dari latar belakang di atas, maka peneliti tertarik untuk mengetahui pengaruh berkumur larutan madu terhadap indeks plak pada siswa-siswi kelas VI SD Negerii 066038 Medan.

Adapun tujuan umum darii penelitian ini adalah untuk mengetahui pengaruh berkumur larutan madu terhadap indeks plak pada siswa-siswi kelas VI SD Negerii 066038 Medan.

Manfaat Penelitian

1. Sebagai informasi dan bahan masukan bagi pihak sekolah kelas VI SD Negeri 066038 Medan.

2. Hasil penelitian ini dapat digunakan sebagai data untuk penelitian selanjutnya.

Hipotesis kerja (Ha)

Ada pengaruh larutan berkumur larutan madu terhadap indeks plak pada siswa-siwi SD Negeri 066038 Medan.

\section{METODE}

Jenis penelitian yang digunakan adalah quasi eksperimen dengan rancangan one group pretest-posttest desain. Populasi dalam penelitian inii adalah seluruh siswa/i anak kelas VII SD Negeri 066038 Medan dengan jumlah 160 orang, sementara besar sampel yang diambil adalah 40 orang siswa/i kelas VI (25\% dari populasi). Dalam penelitian diambil data primer yaitu data tentang indeks plak dengan memeriksa langsung rongga mulut sampel dan hasilnya diisi di format pemeriksaan. Sedangkan data sekunder diperoleh dari pihak sekolah yaitu data tentang jumlah siswa-siswi dan lain-lain yang dibutuhkan dalam penelitian.

\section{HASIL \\ 1. Analisa Univariat}

Data yang dikumpulkan adalah hasil penelitian yang dilakukan terhadap siswa-siswi kelas VI SD Negeri 066038 Medan. Pengumpulan data dilakukan dengan pemeriksaan langsung ke mulut siswa-siswi yang menjadi sampel, dengan mengambil data primer dan sekunder. Setelah seluruh data terkumpul, maka dibuat analisa data dengan cara membuat tabel distribusi frekuensi untuk masing-masing kelompok sampel
Tabel 4.1.

Distribusi Frekuensi Indeks Plak Sebelum Berkumur Dengan Larutan Madu Pada 40 Siswa/I kelas VI SD Negeri 066038 Medan Kecamatan Medan Tuntungan

\begin{tabular}{|c|c|c|c|c|}
\hline No & $\begin{array}{c}\text { Kriteria } \\
\text { Indeks } \\
\text { Plak (IP) }\end{array}$ & $\begin{array}{l}\text { Sebelum } \\
\text { berkumur } \\
\text { lararutan } \\
\text { Madu } \\
\end{array}$ & Persentasi & $\begin{array}{l}\text { Rata } \\
\text {-rata }\end{array}$ \\
\hline & & Jumlah siswa & $\%$ & \\
\hline 1 & Baik & 0 & 0 & 0 \\
\hline 2 & Sedang & 27 & 67,5 & 1,58 \\
\hline 3 & Buruk & 13 & 32,5 & 2,28 \\
\hline & Total & 40 & 100 & \\
\hline
\end{tabular}

Dari tabel di atas dapat diketahui bahwa indeks plak siswasiswi sebelum berkumur dengan larutan madu terhadap 40 sampel, Ditemukan 27 yang memiliki rata-rata indeks plak dengan kriteria sedang atau sebesar 1,58 dan 13 yang memiliki rata-rata indeks plak dengan kriteria buruk atau sebesar 2,28 sedangkan untuk indeks plak dengan kriteria baik yaitu 0 , dan rata-rata indeks plak sebelum berkumur dengan larutan madu pada 40 orang sampel adalah sebesar 1,81 .

Tabel 4.2.

Distribusi Frekuensi Indeks Plak Sesudah Berkumur Dengan Larutan Madu Pada 40 Siswa/I Kelas VI SD Negeri 066038 Medan Kecamatan Tuntungan.

\begin{tabular}{|c|c|c|c|c|}
\hline \multirow[t]{2}{*}{ No } & $\begin{array}{l}\text { Kriteia } \\
\text { Indeks } \\
\text { Plak (IP) }\end{array}$ & $\begin{array}{c}\text { Sesudah } \\
\text { Berkumur } \\
\text { Larutan } \\
\text { Madu }\end{array}$ & Persentasi & \multirow[t]{2}{*}{$\begin{array}{l}\text { Rata- } \\
\text { Rata }\end{array}$} \\
\hline & & $\begin{array}{c}\text { Jumlah } \\
\text { Siswa } \\
\end{array}$ & $\%$ & \\
\hline 1 & Baik & 31 & 77,5 & 0,72 \\
\hline 2 & Sedang & 7 & 17,5 & 1,44 \\
\hline 3 & Buruk & 2 & 5 & 2,10 \\
\hline & Total & 40 & 100 & \\
\hline
\end{tabular}

Dari tabel di atas dapat diketahuii bahwa indeks plak siswa-siswai sesudah berkumur dengan larutan madu terhadap 40 sampel, ditemukan 31 yang memiliki rata-rata indeks plak kriteria baik atau sebesar 0,72 dan 7 orang memiliki rata-rata indeks plak kriteria sedang sebesar 1,44 dan 2 memiliki rata-rata indeks plak kriteria buruk yaitu 2,1 dan rata-rata seluruh sampel indeks plak sesudah berkumur dengan larutan madu pada 40 orang sampel adalah sebesar 0,94.

\section{Tabel 4.3.}

Distribusi Frekuensi Rata-Rata Penurunan Indeks Plak Sebelum Dan Sesudah Berkumur Larutan Madu Terhadap Indeks Plak Pada Siswa/I Kelas VI SD Negeri 066038 Medan Kecamatan Medan Tuntungan. 


\begin{tabular}{lllll}
\hline & Kriteia & Sebelum & Sesudah & \\
& Indeks & Berkumur & Berkumur & \\
& Plak & Larutan & Larutan & \\
No & (IP) & Madu & Madu & Selisih \\
\hline & & & & \\
1 & Baik & 0 & 0,72 & 0,72
\end{tabular}

\section{A.2 Analisa Bivariat}

Untuk menguji dua sampel yang berpasangan maka digunakan paired sample t-Test. Dimana dengan uji t-Test ini dapat diketahui apakah ada pengaruh berkumur larutan madu terhadap index plak. Adapun hasil t-Test yang dilakukan dengan menggunakan Komputer adalah sebagai berikut:

Berdasarkan Perbanding t hitung dengan t Tabel: Jika thitung $<\mathrm{t}$ tabel

$=$ Hipotesis diterima

T hitung $>\mathrm{t}$ tabel

$=$ Hipotesis ditolak

Dari tabel di atas diketahui bahwa hitung adalah 14,755.

Sedangkan $\mathrm{t}$ Tabel bisa dihitung menggunakan tabel $\mathrm{t}$ dengan cara:

Tingkat signifikan (a) adalah $5 \%$ dan df (degree of freedom) atau derajat kebebasan

$$
=\mathrm{n}-1=40-1=39 \text {. }
$$

t-Tabel adalah 2,022

$14,755>2,022$

Hasil perhitungan dari uji t-Test dependent terlihat bahwa hipotesis nol (Ho) ditolak yang berartii ada pengaruh berkumur larutan madu terhadap indeks plak. Sehingga dapat disimpulkan bahwa berkumur dengan larutan madu dapat menurunkan indeks plak.

\section{PEMBAHASAN}

Penelitian ini mengambil sampel sebanyak 40 siswa-siswi kelas VI SD Negeri 066038 Medan kecamatan Medan Tuntungan yang dipilih secara acak untuk berkumur larutan madu. Dari hasil penelitian yang telah dilakukan maka diketahui bahwa banyak siswa-siswi yang memiliki indeks plak dengan kriteria sedang dan buruk yang artinya masih rendahnya tingkat kebersihan gigi dan mulut.

Berdasarkan pemeriksaan awal yang telah dilakukan terhadap seluruh sampel diketahui bahwa ratarata indeks awal sebelum berkumur dengan larutan madu yaitu 1,81, dan setelah berkumur larutan madu, kriteria indeks plak berubah dimana rata-rata indeks plak 0,94.

Dari hasil perhitungan t-test dependent didapatkan hasil bahwa $\mathrm{p}<0,05$ atau 0,000 $<0,05$ sehingga hipotesis nol (Ho) ditolak yang berarti dapat menurunkan nilai indeks plak pada siswa-siswi kelas VI SD Negeri 066038 Medan Kecamatan Tuntungan.

Dengan hasil tersebut maka terlihat jelas bahwa berkumur larutan madu dapat menurunkan nilai indeks plak gigi. Salah satu pencegah plak gigi dapat dilakukan secara kimiawi yaitu berkumur-kumur (Besford, 1996).

Jadi menyingkirkan plak dari permukaan gigi tidak hanya dilakukan dengan menyikat gigi saja, namun juga bisa dilakukan dengan cara berkumur dengan larutan madu.

\begin{tabular}{lllll}
2 & Sedang & 1,58 & 1,44 & 0,14 \\
3 & Buruk & 2,28 & 2,1 & 0,18 \\
\hline
\end{tabular}

Karena larutan madu sangat efektif untuk mencegah kerusakan gigi (Hamad, 2007).

Sifat madu yang membunuh bakteri disebut efek inhibisi, sifat ini meningkat dua kali lipat bila diencerkan dengan air (Purbaya, 2007). Menurut Sarwono (2001), aktivitas antibakteri utama di madu adalah terkait dengan hidrogen peroksida yang terbentuk secara enzimatis. Tingkat hidrogen peroksida yang diproduksi bersifat antibakteri, namun tidak membahayakan jaringan tubuh. Berkumur madu encer kurang lebih $15 \%$ dapat menyembuhkan radang rongga mulut.

\section{SIMPULAN}

Dari hasil penelitian yang telah dilakukan oleh peneliti maka dapat disimpulkan bahwa:

1. Rata-rata indeks plak awall sebelum berkumur dengan larutan madu yaitu 1,81 .

2. Rata-rata indeks plak akhir setelah berkumur dengan larutan madu yaitu 0,94 .

3. Larutan madu dapat menurunkan nilai indeks plak.

\section{SARAN}

Sesuai dengan hasil penelitian yang telah dilakukan, diharapkan:

1. Kepada siswa-siswi Kelas VI SD Negeri 066038 Medan Kecamatan Medan Tuntungan lebih meningkatkan menjaga kesehatan gigi dan mulut serta upaya pencegahan penyakit gigi dan mulut dengan pembersihan plak.

2. Kepada siswa-siswi Kelas VI SD Negeri 066038 Medan Kecamatan Medan Tuntungan dapat meningkatkan kesehatan gigi dan mulut dengan pemeliharaan kesehatan gigi dan mulut dengan menggunakan obat tradisional terutama madu.

3. Kepada siswa-siswi kelas VI SD Negeri 066038 Medan Kecamatan Medan Tuntungan agar lebih giat untuk menjaga kebersihan gigi minimal 2 kali sehari, pagi sesudah sarapan dan malam sebelum tidur, memeriksakan gigi ke dokter gigi tiap 6 bulan sekali. 


\section{DAFTAR PUSTAKA}

Arikunto, Suharnisi, (2008). Prosedur Penelitian Suatu Pendapat Praktek. Jakarta. Rineka Cipta.

Elija Herjualianti. (2002), Pendidikan Kesehatan Gigi Airlangga University Press, Surabaya.

http://www. Purbalinggakab.com. (2011).

Panjaitan Monang, (1995). Etioilogi Karies Gigi dan Penyakit Jaringan Periodontal, USU Press, Jakarta.

Notoatmodjo, S. (2010). Metodologi Penelitian Kesehatan. Jakarta: Rineka Cipta

Pintauli Sondang, Taizo Hamada, (2010). Metode Gigi dan Mulut Sehat, USU Press, Medan.Data.

Purbaya, J.Rio, (2007). Mengenal Madu Alami, Pioner Jaya, Bandung.

Rostita. (2014). Berkat Madu Sehat, Cantik, dan Penuh Vitalitas. PT Mizan Pustaka. Bandung.

Team Darul Hadharah. (2014). Sehat Dengan Terapi Madu. Solo : Kiswah Madia.

Tim Karya Tadi Mandiri. (2010). Pedoman Budaya Lebah Madu. Bandung : CV Nuansa Aulia.

Zainul Akbar. (2014). Jurus Sehat Rasulullah, Bandung : Sygma Creatitive Media Crorp. 